\title{
Genetic diversity among different geographical isolates of the gram pod borer, Helicoverpa armigera (Hübner) (Lepidoptera: Noctuidae) nucleopolyhedrosis virus (HearNPV)
}

\author{
Ranvir Singh ${ }^{1 *}$, K. S. Jagadish ${ }^{1}$, Kheta Ram Tak ${ }^{2}$ and Anitha Peter ${ }^{2}$
}

\begin{abstract}
The gram pod borer, Helicoverpa armigera (Hübner) (Lepidoptera: Noctuidae), is infected by nucleopolyhedrosis virus (HearNPV), which is the most promising microbial biocontrol agent of the pest. A genetic diversity analysis of geographically distinct isolates of HearNPV was done, using the polyhedrin (polh) gene of the viruses that encodes a major structural protein of the occlusion bodies. The gene was amplified and isolated from eight Indian isolates, using the polymerase chain reaction (PCR). These sequences were compared with the polh genes of other HearNPV from different geographical regions of the world. A phylogenetic tree was constructed, using polh nucleotide/deduced amino acid sequences to know their genetic relatedness. The polh gene of isolates originating from nearby locations clustered together with the gene of isolates in the present study; however, some showed relatedness with gene isolate from other geographically distinct isolates, with respect to the genetic distances among them. The Indian isolate (BanPDBC-In) shared lower genetic distance of 0.0020 to 0.0040 substitutions per site with the Spanish isolates SP1A-Sp and SP1B-Sp and clustered in one group based on nucleotide sequences. The isolates showed different a clustering pattern in phylogenetic tree based on deduced amino acid sequences than that of the nucleotide sequences. The overall genetic distances between polh nucleotides ranged from 0.0000 to 0.0203 substitutions per site, while it was 0.0000 to 0.0121 between deduced amino acid sequences. Among different geographical groups of isolates, the Indian group showed the highest genetic diversity based on both polh nucleotide $(0.0070 \pm 0.0002$ substitutions per site) and deduced amino acid ( $0.0057 \pm 0.0003$ substitutions per site) sequences among different groups of geographical isolates. A diversity analysis of virus isolates can aid in the selection and identification of virulent virus isolates for the development of a virus-based bio-pesticide formulation.
\end{abstract}

Keywords: Helicoverpa armigera, nucleopolyhedrosis virus, isolates, phylogeny, polyhedrin

\section{Background}

The gram pod borer, Helicoverpa armigera (Hübner) (Lepidoptera: Noctuidae), is a cosmopolitan and polyphagous insect pest (Fitt 1989). It has been reported to feeding on 60 cultivated and 67 wild host plants in 36 families (Reed and Pawar 1982). The pest is known to cause an estimated loss of more than US \$2 billion

\footnotetext{
* Correspondence: ranvirverma11@gmail.com

${ }^{1}$ Department of Agricultural Entomology, University of Agricultural Sciences,

GKVK campus, Bengaluru, Karnataka 560065, India

Full list of author information is available at the end of the article
}

annually in semi-arid tropics (Sharma et al. 2005). Several entomopathogenic microbes were exploited for the management of this pest (Swami et al. 2012; Pugalenthi et al. 2013; Bajya et al. 2015). Among these, $H$. armigera nucleopolyhedrosis virus (HearNPV) has attracted much attention because of its host specificity and safety to non-target organisms (Moore et al. 2004; Gupta et al. 2010). However, HearNPV isolates collected from different geographical regions showed considerable variations both in genetics and in virulence (Ogembo et al. 2007; Mehrvar et al. 2008; Figueiredo et al. 2009). Thus, the 
study of the diversity among geographical isolates of HearNPV, at molecular level, is a key research area to generate information on molecular fingerprinting for selecting virulent virus isolates (Kaur et al. 2014).

HearNPV belongs to the family baculoviridae of the insect viruses. They have rod-shaped virions, enveloped in proteinaceous occlusion bodies with supercoiled doublestranded circular DNA genome ranging from 90 to $160 \mathrm{~kb}$ (Blissard and Rohrmann 1990; Zhang et al. 2005). In earlier studies, the baculoviruses were differentiated based on restriction enzyme analysis of whole genome (Gettig and McCarthy 1982; Takatsuka et al. 2003). Highly conserved genes such as polyhedrin (polh) (Rohrmann 1986), late expression factors (Hefferon 2004), and chitinase (Wang et al. 2004) have been identified in baculoviruses. Polyhedrin gene among these encodes major matrix protein of occlusion bodies of baculoviruses (Blissard and Rohrmann 1990). PCR-based amplified sequence of these genes have been used for diversity studies by many scientific groups (Jakubowska et al. 2005; Arrizubi et al. 2013; Kaur et al. 2014) and classification of baculoviruses (Lange et al. 2004; Jehle et al. 2006).

In the present study, genetic diversity of HearNPV from different geographical regions (HearNPV isolates) was studied based on the variations in the sequence of polh gene sequence.

\section{Materials and methods Insect rearing}

$H$. armigera was reared on a semisynthetic chickpea diet at $25^{\circ} \mathrm{C}$ and 16-h photoperiod (Wakil et al. 2011).

\section{Multiplication of virus isolates}

The crude extracts of polyhedral inclusion bodies (PIBs) were obtained from various institutions located in different regions of India as listed in Table 1.

The virus isolates were multiplied in fourth-instar larvae of $H$. armigera. The larvae were fed on a semisynthetic diet mixed with polyhedral suspension $\left(6.5 \times 10^{9} \mathrm{PIBs} / \mathrm{ml}\right)$ of virus and incubated at $25^{\circ} \mathrm{C}$. The infected larvae were collected based on typical disease symptom and homogenized in distilled water. The mixture was filtered through a clean muslin cloth, and the polyhedra were ultrapurified on a 40 to $60 \%$ sucrose gradient in a Beckmann centrifuge at $32000 \mathrm{rpm}$. The isolated polyhedral were stored in distilled water at $-20{ }^{\circ} \mathrm{C}$. The concentration of polyhedra in each virus suspension was determined, using Neubauer Haemocytometer under phase contrast light microscope at $\times 400$ (Grzywacz et al. 2004).

\section{DNA isolation}

The DNA was extracted from different isolates according to the protocol of Figueiredo et al. (1999) with slight modifications. The purified polyhedra were re-suspended in $0.1 \mathrm{M}$ sodium carbonate solution [0.1 $M$ sodium carbonate, $0.15 \mathrm{M} \mathrm{NaCl}, 0.5 \mathrm{M}$ EDTA ( $\mathrm{pH}$ 10.5)] and incubated at $37{ }^{\circ} \mathrm{C}$ for $15 \mathrm{~min}$. Subsequently, $0.5 \mathrm{mg} / \mathrm{ml}$ of proteinase $\mathrm{K}$ and $1 \%$ SDS (sodium dodecyl sulphate) was added and incubated at $37{ }^{\circ} \mathrm{C}$ for $15 \mathrm{~min}$. The digested solution was further extracted by phenol and then by phenol to chloroform to isomyl alcohol $(25: 24: 1)$ solution. The DNA was precipitated by ethanol and re-suspended in 0.1 $\mathrm{X}$ TE buffer ( $\mathrm{pH}$ 8.0).

\section{PCR amplification of polyhedrin (polh) gene}

Primers for the specific amplification of polh from HearNPV isolates were designed based on polh sequence of the Project Directorate of Biological Control, Bangalore (PDBC) isolate (GenBank acc. no. FJ 157293.1), using Primer3 (Version 0.4.0) software. The reaction mixture $(20 \mu \mathrm{l})$ contained $15 \mathrm{ng}$ DNA template, $3 \mathrm{U}$ Taq DNA polymerase, $10 \mathrm{pmol} / \mu \mathrm{l}$ forward primer (5'-ATGTATACTCGTTACAGTTACA GCCCT-3'), $10 \mathrm{pmol} / \mu \mathrm{l}$ reverse primer (5'-TTAATA TGCAGGACCAGTGTATAGC-3'), 2 mM dNTPs, and 10X PCR buffer with $15 \mathrm{mM} \mathrm{MgCl}_{2}$.

The gene amplification was performed, using a thermal cycler (Bio-Rad), with initial denaturation at $94{ }^{\circ} \mathrm{C}$ for $4 \mathrm{~min}$ followed by another denaturation at

Table 1 Helicoverpa armigera nucleopolyhedrosis virus (HearNPV) isolates from various geographical locations in India

\begin{tabular}{llll}
\hline SI. no. & \multicolumn{1}{c}{ Virus isolate } & Abbreviation & Geographic coordinates \\
\hline 1 & Dhule, Maharashtra & Dhl-In & $20.9042^{\circ} \mathrm{N}, 74.7749^{\circ} \mathrm{E}$ \\
2 & Akola, Maharashtra & Akl-In & $20.7002^{\circ} \mathrm{N}, 77.0082^{\circ} \mathrm{E}$ \\
3 & Rajanukunte, Karnataka & Rke-In & $13.1870^{\circ} \mathrm{N}, 77.5502^{\circ} \mathrm{E}$ \\
4 & Chandapura, Karnataka & Chan-In & $12.8005^{\circ} \mathrm{N}, 77.7136^{\circ} \mathrm{E}$ \\
5 & Gulbarga, Karnataka & Gul-In & $17.3297^{\circ} \mathrm{N}, 76.8343^{\circ} \mathrm{E}$ \\
6 & Hyderabad, Telangana State & Hyd-In & $17.3850^{\circ} \mathrm{N}, 78.4867^{\circ} \mathrm{E}$ \\
7 & Udaipur, Rajasthan & Udr-In & $24.5854^{\circ} \mathrm{N}, 73.7125^{\circ} \mathrm{E}$ \\
8 & Hosur, Tamil Nadu & Hor-In & $12.7409^{\circ} \mathrm{N}, 77.8253^{\circ} \mathrm{E}$ \\
\hline
\end{tabular}


$94{ }^{\circ} \mathrm{C}$ for $1 \mathrm{~min}$, and then annealing at $57{ }^{\circ} \mathrm{C}$ for 45 s, followed by extension at $72{ }^{\circ} \mathrm{C}$ for $1 \mathrm{~min}$ and a final extension at $72{ }^{\circ} \mathrm{C}$ for $10 \mathrm{~min}$, and the amplified polh gene was subsequently stored at $4{ }^{\circ} \mathrm{C}$ until used. There were 35 amplification cycles. The amplified PCR product was electrophoresed in $0.8 \%$ agarose gel and visualized in a UV gel documentation system.

\section{Sequencing of amplified product}

The agarose gel bands with polh gene amplimers were eluted from the agarose block and purified, using

Table 2 Geographical isolates of Helicoverpa armigera nucleopolyhedrosis virus (HearNPV) used to compare with the eight isolates from present study

\begin{tabular}{|c|c|c|c|c|c|}
\hline SI. no. & Origin/group & Isolate & Abbreviation & $\begin{array}{c}\text { Accession } \\
\text { (nucleotide) }\end{array}$ & $\begin{array}{c}\text { Accession } \\
\text { (amino acid) }\end{array}$ \\
\hline 1 & India & Jodhan & Jod-In & FJ157294.1 & ACI05105.1 \\
\hline 2 & & Ludhiana PAU & Lud-PAU-In & FJ157291.1 & ACI05102.1 \\
\hline 3 & & Ludhiana-l & Lud-I-In & KM268536.1 & AlY68501.1 \\
\hline 4 & & Ludhiana-II & Lud-II-In & KY432399.1 & ARQ18915.1 \\
\hline 5 & & Bathinda & Bat-In & FJ157292.1 & ACI05103.1 \\
\hline 6 & & Faridkot-I & Far-I-In & KC174715.1 & AGE92318.1 \\
\hline 7 & & Faridkot-II & Far-II-In & KM357499.1 & AlY24932.1 \\
\hline 8 & & Dhule & Dhl-In & MH029114 & QCA42461 \\
\hline 9 & & Akola & Akl-In & MH029115 & QCA42462 \\
\hline 10 & & Hisar HAU & His-HAU-In & FJ157295.1 & ACI05106.1 \\
\hline 11 & & Palampur & Pal-In & LK031772.1 & CDR35259.1 \\
\hline 12 & & Hyderabad & Hyd-In & MH029116 & QCA42463 \\
\hline 13 & & Udaipur & Udr-In & MH029117 & QCA42464 \\
\hline 14 & & Rajanukunte & Rke-In & MH029111 & QCA42458 \\
\hline 15 & & Chandapura & Chan-In & MH029112 & QCA42459 \\
\hline 16 & & Gulbarga & Gul-In & MH029113 & QCA42460 \\
\hline 17 & & Bangalore & Ban-In & JQ612524.1 & AFD09505.1 \\
\hline 18 & & Bangalore L1 NBAIR & Ban-L1-NBAIR-In & KT013224.1 & ALD88571.1 \\
\hline 19 & & Bangalore PDBC & Ban-PDBC-In & FJ157293.1 & ACI05104.1 \\
\hline 20 & & Hosur & Hor-In & MH029118 & QCA42465 \\
\hline 21 & & 1113 Negamum & 1113-Neg-In & HQ246082.1 & ADY88204.1 \\
\hline 22 & & 2588 Negamum & 2588-Neg-In & HQ246093.1 & ADY88215.1 \\
\hline 23 & China & 1073 China & 1073-Ch & HQ246081.1 & ADY88203.1 \\
\hline 24 & & 1625 China & 1625-Ch & HQ246090.1 & ADY88212.1 \\
\hline 25 & & 3010 China & 3010-Ch & HQ246094.1 & ADY88216.1 \\
\hline 26 & South Africa & 1186 South Africa & $1186-S A$ & HQ246085.1 & ADY88207.1 \\
\hline 27 & Sudan & 75 Sudan & 75-Sud & HQ246071.1 & ADY88193.1 \\
\hline 28 & Spain & LB1 Spain & LB1-Sp & KJ701029.1 & AJP07155.1 \\
\hline 29 & & LB3 Spain & LB3-Sp & KJ701030.1 & AJP07290.1 \\
\hline 30 & & LB6 Spain & LB6-Sp & KJ701031.1 & AJP07425.1 \\
\hline 31 & & SP1A Spain & SP1A-Sp & KJ701032.1 & AJP07560.1 \\
\hline 32 & & SP1B Spain & SP1B-Sp & KJ701033.1 & AJP07696.1 \\
\hline 33 & Poland & 138 Poland & 138-Pol & HQ246073.1 & ADY88195.1 \\
\hline 34 & Australia & Australia & Aus & JN584482.1 & AEN03926.1 \\
\hline 35 & & H25EA1 Australia & AC53-Aus & KJ922128.1 & AlG63180.1 \\
\hline 36 & & AC53 Australia & H25EA1-Aus & KJ909666.1 & AIG63043.1 \\
\hline
\end{tabular}


GeneJET gel extraction kit (Thermo Scientific). The purified DNA fragments were ligated to pTZ57R/T easy cloning plasmid vector, using "InsTAclone ${ }^{\text {Tm }}$ PCR Cloning Kit" (Fermentas Life Sciences) and sequenced by using M13 forward and reverse primers from AgriGenome Labs Pvt. Ltd., India. The resulting sequences were extracted, using BioEdit 7.2.1 software. Homology searches were performed, using BLAST program (Altschul et al. 1990) of NCBI website. The polh gene sequences were translated to protein, using protein translation tool ExPASy (Expert Protein Analysis System).

\section{Genetic diversity analysis}

The polh sequences amplified from eight isolates were compared with those from other geographical isolates to infer the genetic diversity. The polh sequences belonging to different geographical regions were obtained from the GenBank database (Table 2). Phylogenetic tree was constructed from the aligned polh nucleotide/deduced amino sequences with maximum likelihood method by following bootstrap method (replications $=1000$ ) for variance estimation. The granulin sequence (PlxyGV-001-gran-SA) (AN: KJ939451.1) was used as an out-group. The pairwise genetic distance, which estimates number of nucleotide/amino acid substitutions per site between a pair of sequences, was determined. The analyses were carried out with MEGA 6.0 software (Tamura et al. 2013). The genetic diversity among different continents was estimated using DIVEIN software, which measures the mean genetic distances between groups of sequences (Deng et al. 2010). Kimura-2-parameter (Kimura 1980) and Jones-Taylor-Thornton substitution models (Jones et al. 1992) estimation were used for nucleotide and amino acid sequences comparison, respectively.

\section{Results and discussion}

Amplification with polh-specific primers gave an amplimer of approximately of $740 \mathrm{bp}$ from all the eight HearNPV isolates (Fig. 1). BLAST results of sequenced DNA fragments showed 99 to $100 \%$ similarity with the previously deposited polh sequences in the GenBank database. This confirmed the identity of the gene in the eight isolates used in the present study as polh. The resulting sequences were submitted to the GenBank database, with accession number as, MH029111, MH029112, MH029113, MH029114, MH029115, MH029116, MH029117, and MH029118 for Rajanukunte, Chandapura, Gulbarga, Dhule, Akola, Hyderabad, Udaipur, and Hosur isolates, respectively.

The genetic relatedness of different geographical isolates was determined by phylogenetic analysis of their polh sequences. The isolates were clustered into two clades (Clade1and Clade2) based on their polh nucleotide sequences (Fig. 2a). Clade2 was further divided into subclades. Most of the isolates were clustered with related geographical isolates, however, some with geographically distant isolates too. The two Indian isolates (2588-Neg-In and 1113-

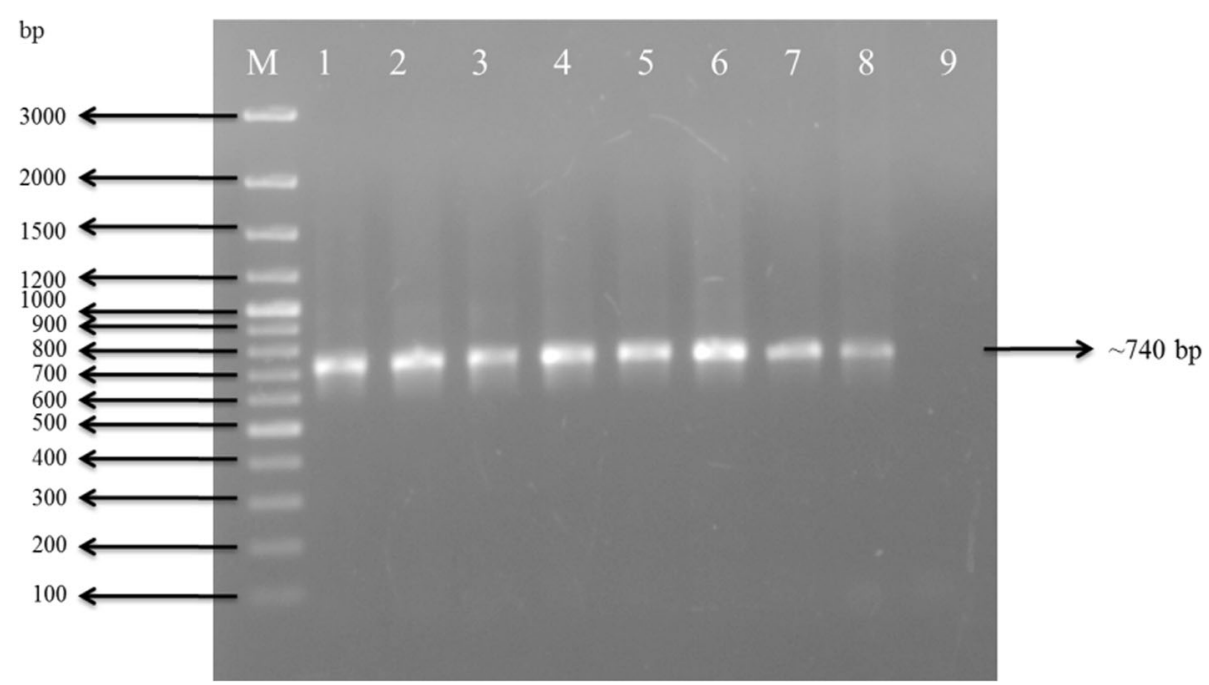

Fig. 1 Electrophoretic profile of polyhedrin gene amplified from total DNA of different geographical isolates of HearNPV (M: Marker: 100bp ladder (Thermoscientific); Lane 1: Rke-In; 2: Chan-In; 3: Gul-In; 4: Dhl-In; 5: Akl-In; 6: Hyd-In; 7: Udr-In; 8: Hor-In; 9: Non template control 


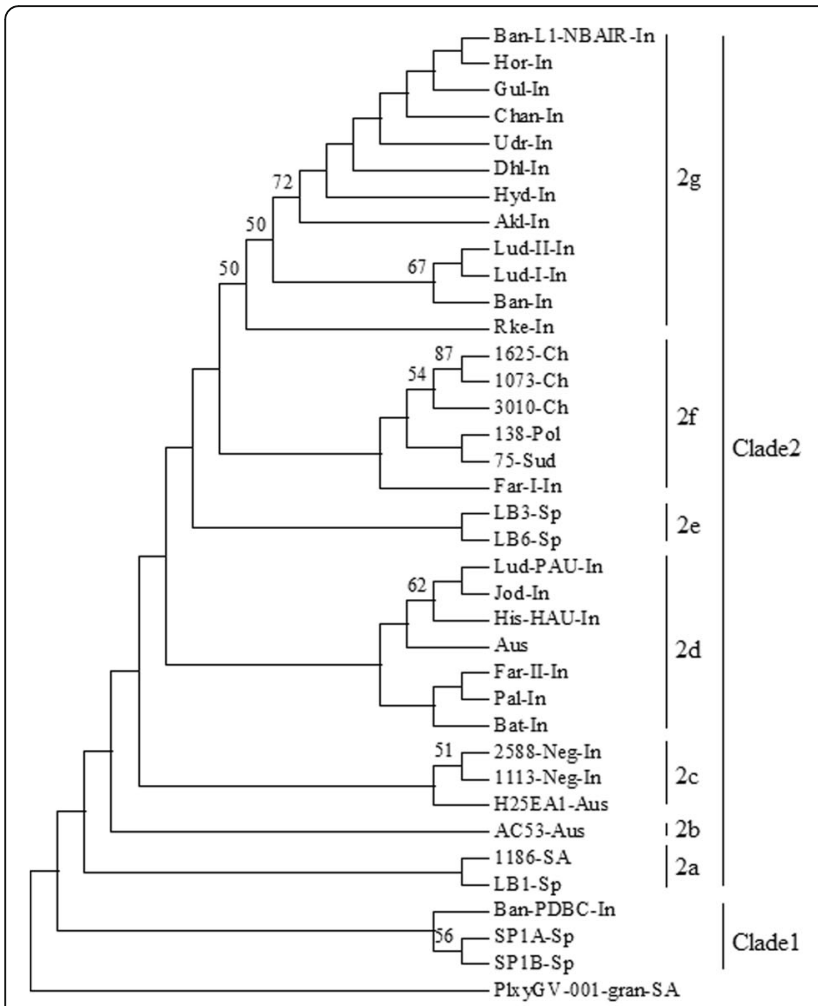

(a)

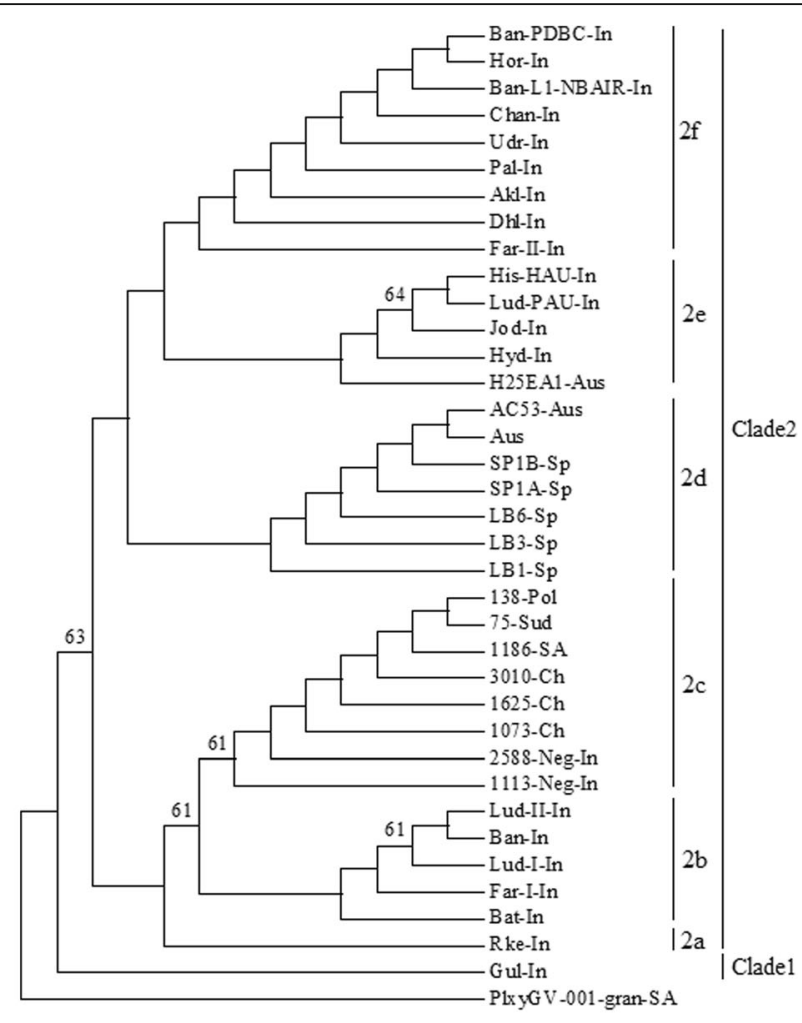

(b)

Fig. 2 Phylogenetic tree based on polyhedrin nucleotide (a)/ deduced amino acid sequences (b) of HearNPV isolates from different geographical regions

Neg-In) formed a cluster with Australian isolate (H25EA1-Aus). Likewise, another Indian isolate (Far1-In) showed relatedness with isolates from Sudan, Poland, and China. The isolates clustered with respect to the genetic distances among them. The Indian isolate (Ban-PDBC-In) shared a lower genetic distance of 0.0020 to 0.0040 substitutions per site (Table 3) with the Spanish isolates SP1A-Sp and SP1B-Sp and clustered in Clade1. It had genetic distance of 0.0040 to 0.0141 substitutions per site with other isolates.

Phylogenetic tree of deduced amino acid sequences showed a different clustering pattern than nucleotide sequences (Fig. 2b). The isolate (Ban-PDBC-In) clustered with geographically related Indian isolates. In contrast, it was placed with Spanish isolates (SP1ASp and SP1B-Sp), when analyzed based on nucleotide sequences. The overall genetic distances between polh nucleotide sequences ranged from 0.0000 to 0.0203 substitutions per site, while it ranged from 0.0000 to 0.0121 substitutions per site between deduced amino acid sequences (Table 3). This showed that polh protein is relatively conserved in the isolates, although there was a slightly higher variation in the nucleotide sequences.

The highest genetic diversity was reported in a group of isolates from India based on both polh nucleotide $(0.0070 \pm 0.0002$ substitutions per site $)$ and deduced amino acid $(0.0057 \pm 0.0003$ substitutions per site $)$ sequences (Table 4, Fig. 3). The groups of isolates from other continents showed zero diversity in amino acid sequences, although with some diversity in their nucleotide sequences.

The present findings showed genetic variations in geographically unrelated HearNPV isolates. Similar kinds of results were reported by many scientific groups, in different nucleopolyhedrosis viruses infecting different insects. Kaur et al. (2014) observed that the HearNPV isolates originating from closer locations were placed in one cluster in a phylogenetic tree. However, one Indian isolate (Bangalore) showed that it was closely related with isolates from Kenya, Israel, and South Africa. According to Rowley et al. (2011), some Indian and Chinese isolates were phylogenetically related with geographically distinct isolates. Many studies have reported genetic 


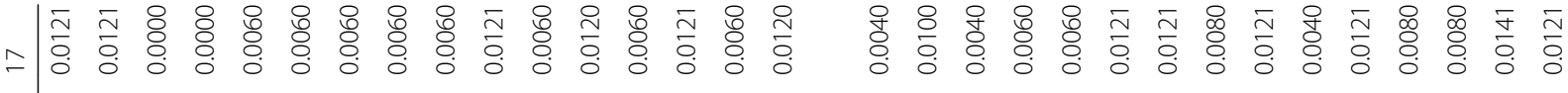

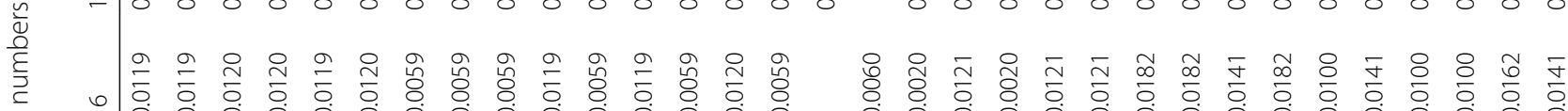

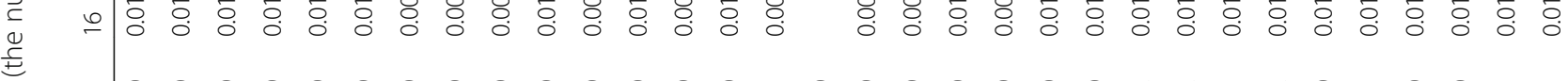

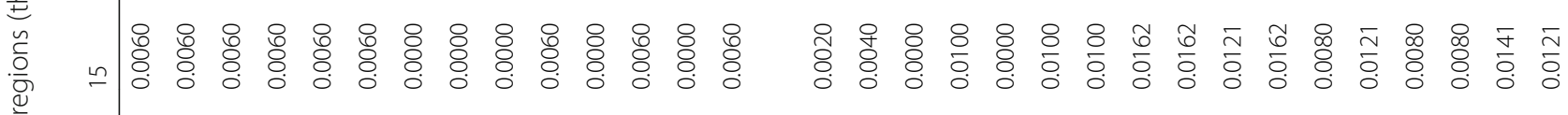

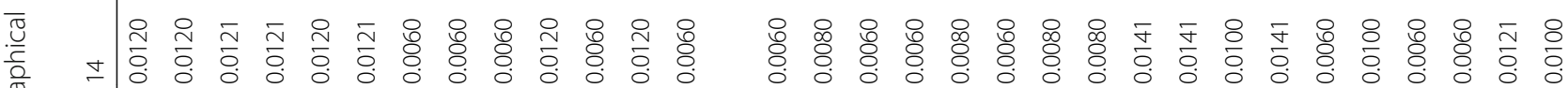

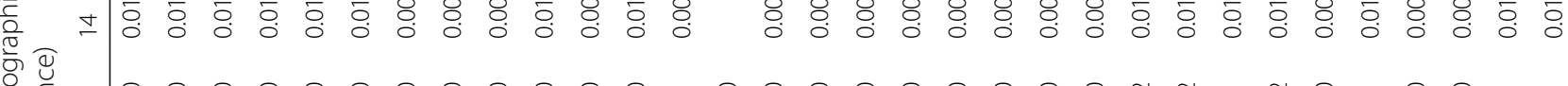

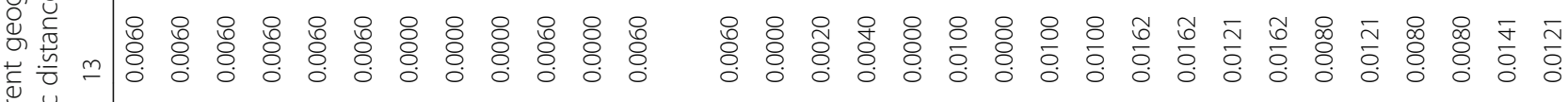

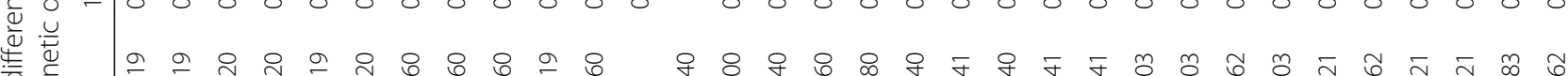

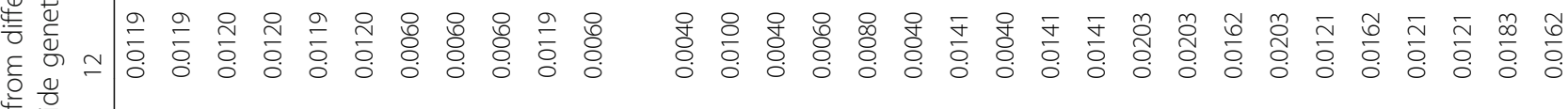

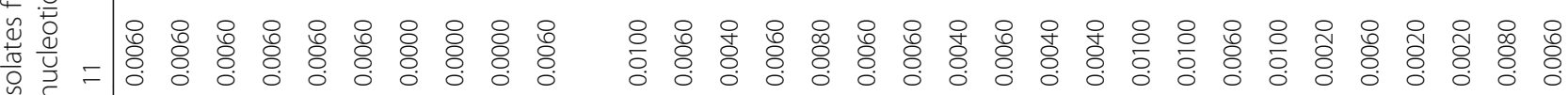

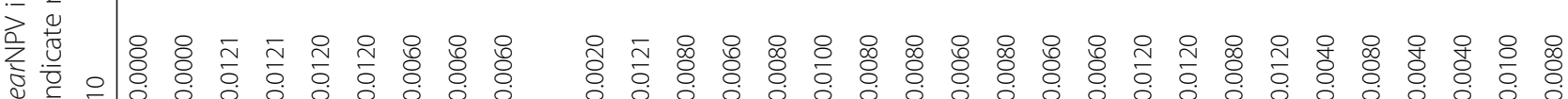

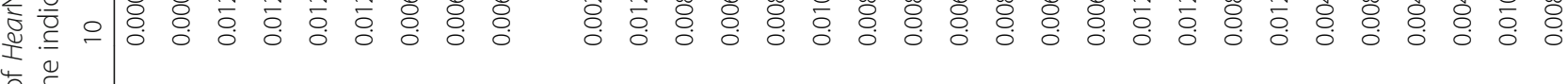

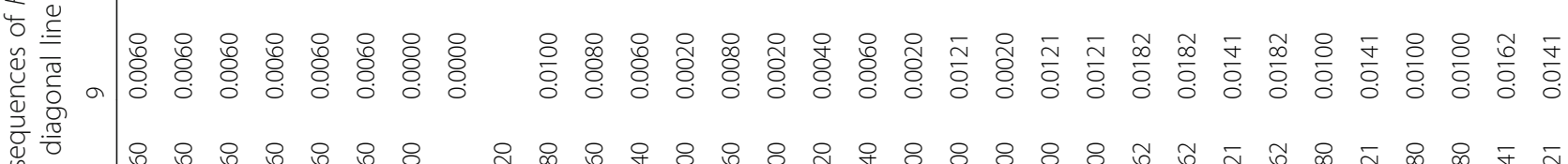

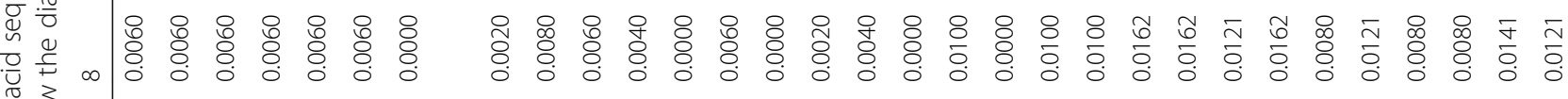

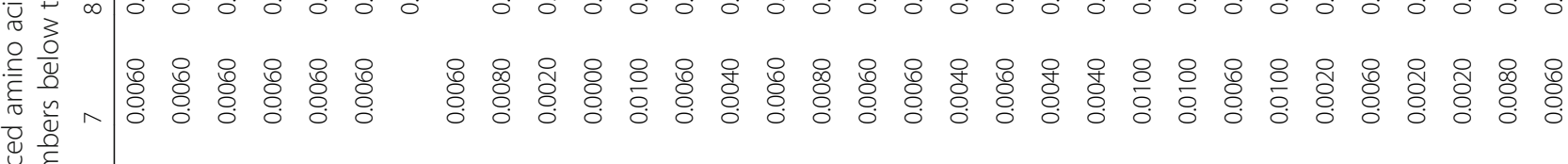

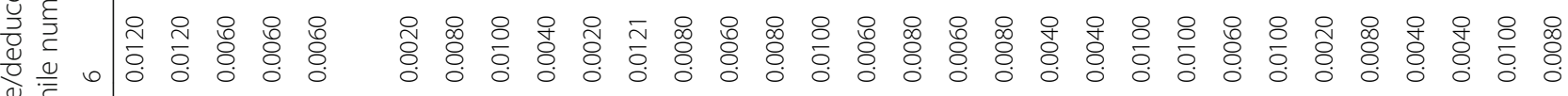

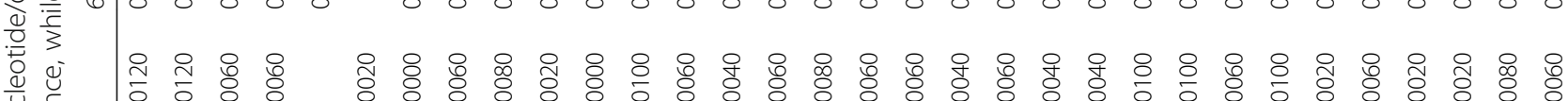

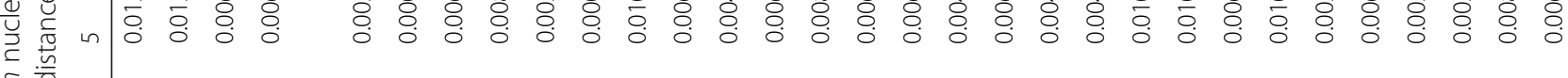

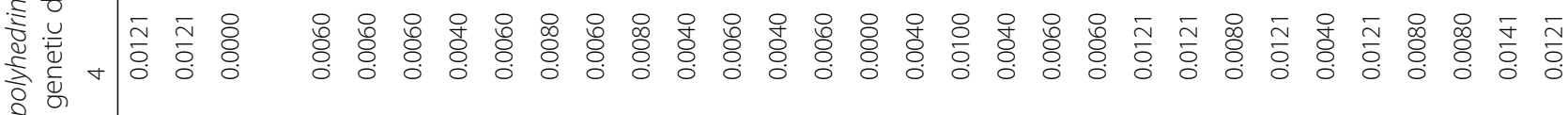

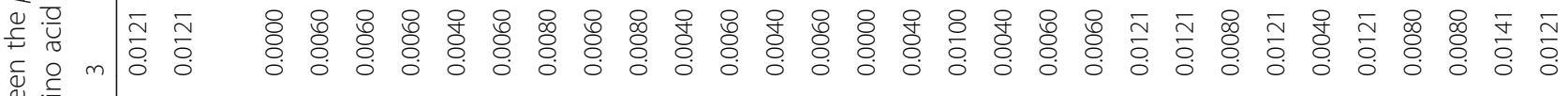

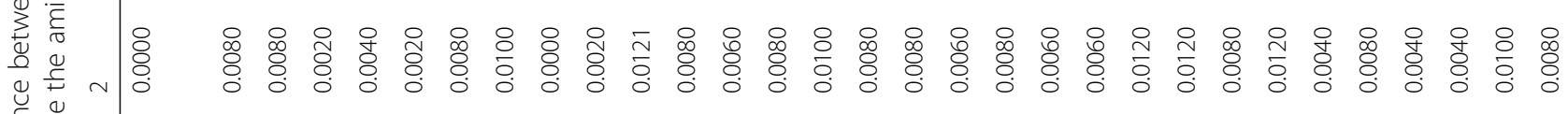

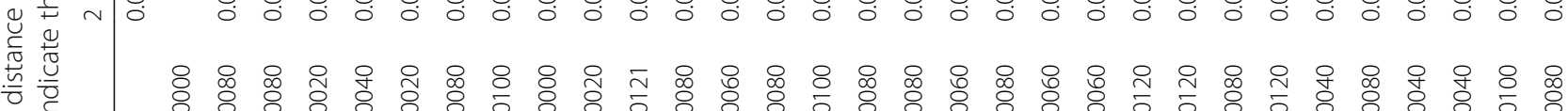

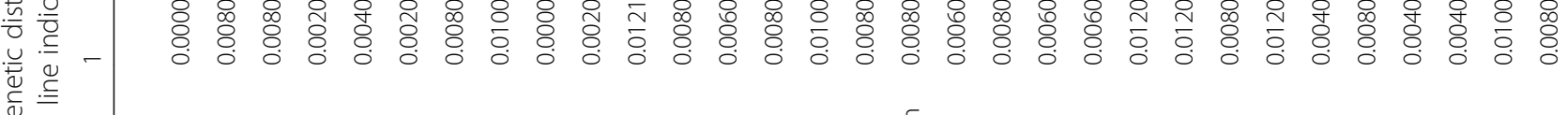

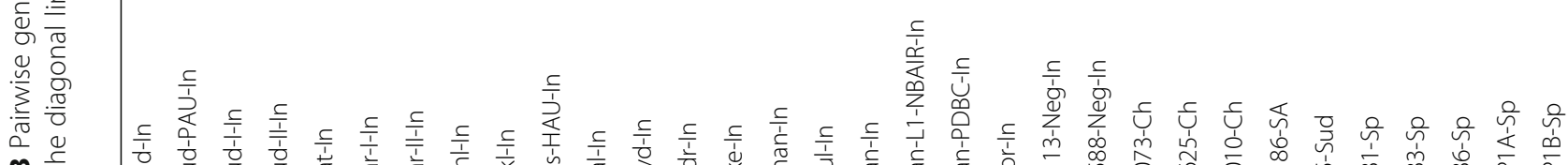

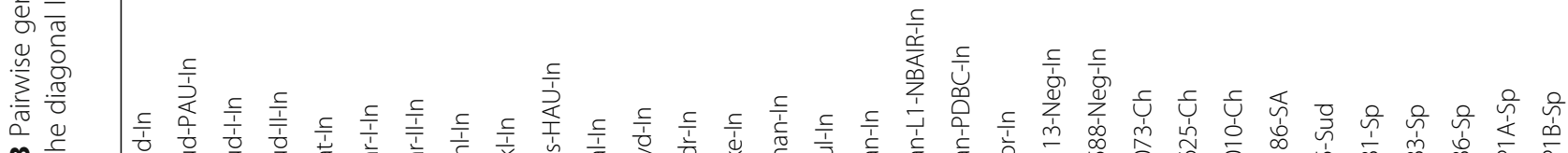

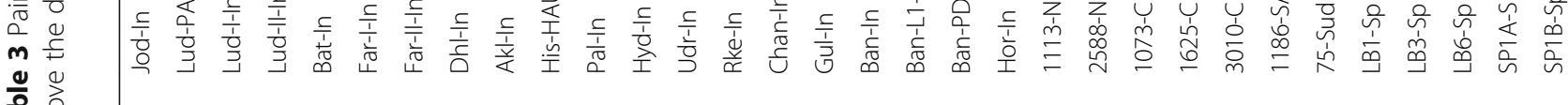
高亳 | 


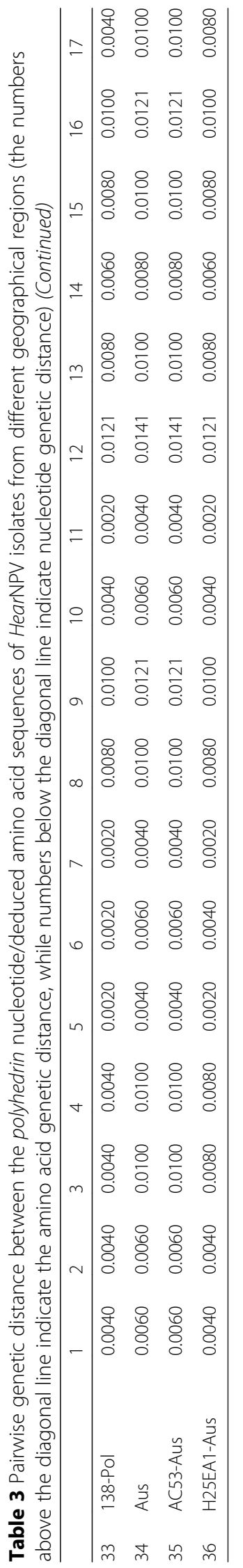




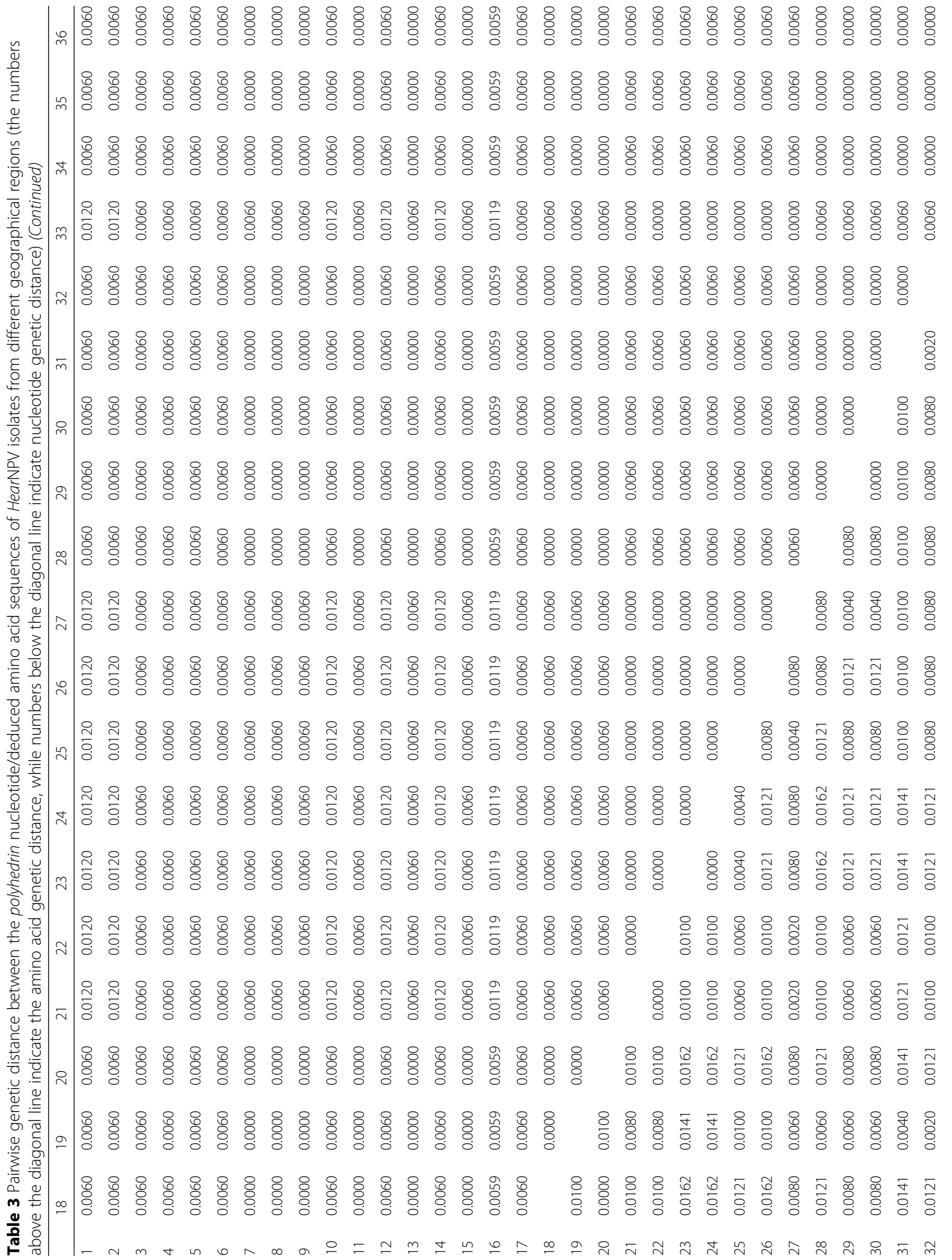




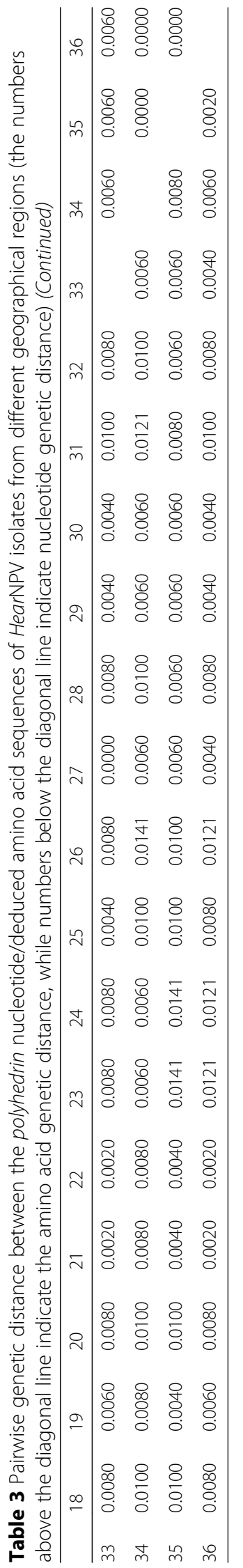


Table 4 Pairwise genetic diversity of groups of HearNPV isolates from different continents

\begin{tabular}{|c|c|c|c|}
\hline \multirow[t]{2}{*}{ Group } & \multirow{2}{*}{$\begin{array}{l}\text { Number } \\
\text { of } \\
\text { sequences }\end{array}$} & \multicolumn{2}{|l|}{ Genetic diversity } \\
\hline & & $\begin{array}{l}\text { Nucleotide } \\
\text { Mean } \pm \text { S.E. }\end{array}$ & $\begin{array}{l}\text { Amino acid } \\
\text { Mean } \pm \text { S.E. }\end{array}$ \\
\hline Australia & 3 & $0.0054 \pm 0.0014$ & $0.0000 \pm 0.0000$ \\
\hline Poland & 1 & $0.0000 \pm 0.0000$ & $0.0000 \pm 0.0000$ \\
\hline Spain & 5 & $0.0065 \pm 0.0010$ & $0.0000 \pm 0.0000$ \\
\hline Sudan & 1 & $0.0000 \pm 0.0000$ & $0.0000 \pm 0.0000$ \\
\hline South Africa & 1 & $0.0000 \pm 0.0000$ & $0.0000 \pm 0.0000$ \\
\hline China & 3 & $0.0039 \pm 0.0011$ & $0.0000 \pm 0.0000$ \\
\hline India & 22 & $0.0070 \pm 0.0002$ & $0.0057 \pm 0.0003$ \\
\hline
\end{tabular}

variation in geographically distinct baculoviruses based on the restriction fragment analysis of whole genomes. HearNPV isolates collected from Spain and Portugal showed genetic variations based on their restriction fragment profile (Figueiredo et al. 1999). Similar kinds of results were found in restriction endonuclease analysis of Spodoptera litura NPV and S. littoralis NPV from Japan, Vietnam, Malaysia, India, and Egypt (Takatsuka et al. 2003) also revealed similar findings. The regional isolates of HearNPV from India (Patel et al. 2009) and S. frugiperda NPV from Brazil (Barreto et al. 2005) showed differences in their RAPD profiling. The HearNPV samples collected from South Africa, Zimbabwe, Thailand, and Kenya were identified as variants of the same baculovirus (Ogembo et al. 2007).

There are several hypotheses for pathogen genotypic variations, including host immune response specificity, trade-offs between pathogen fitness components, interactions between pathogen genotypes within hosts, and differential selection of pathogen genotypes. Pathogen genotypes with low fitness in some hosts may be sustained in populations by having relatively high fitness under different ecological conditions. In other words, genotypic variation in pathogen populations may be promoted by genotype $(\mathrm{G})$, environment $(E)$, and $\left(G^{*} E\right)$ interactions acting at the level of the pathogen genotype (Hodgson et al. 2002). The other reasons for these variations could be due to the insertion of host DNA into the viral genome, duplication of virus sequences, insertions, deletions, and point mutations in the viral DNA.

These whole genome or gene-specific genotypic variations can be used as a genetic marker for understanding of the biodiversity of the viruses, their evolution patterns, and recombination. This understanding combined with bioassay studies could lead to develop or engineer potent biological control agents (BCAs) suitable for pests distributed over wide geographical areas or integrate such BCAs with management strategies to make them more efficient, economical, and environmentally safe.

\section{Conclusion}

The present study revealed genetic variations among the HearNPV isolates belonging to different geographical regions. This information can be further validated by studying other highly conserved genes. The genetic variations coupled with bioassay studies can be used for the selection of most virulent isolates for the designing commercial formulations.

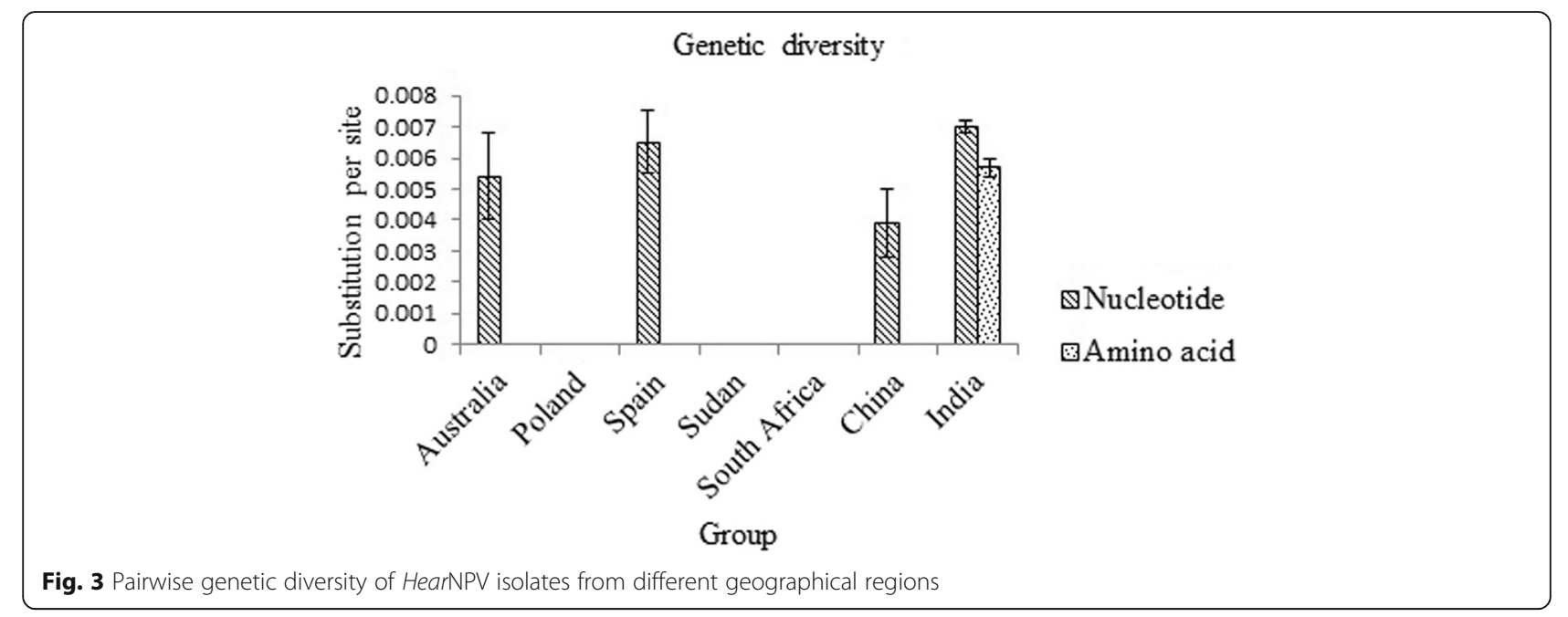




\section{Abbreviations}

HearNPV: Helicoverpa armigera nucleopolyhedrosis virus; polh: polyhedrin

\section{Acknowledgements}

The author are very grateful to National Bureau of Agricultural Insect Resources (NBAIR), Bengaluru, Zonal Agricultural Research Station, Gulbarga, Maharana Pratap University of Agriculture and Technology, Udaipur, M/s Agri Life Pvt. Ltd., Hyderabad, Dr. Panjabrao Deshmukh Krishi Vidyapeeth, Akola, College of Agriculture and Mahatma Phule Krishi Vidyapeeth (MPKV), Dhule for providing HearNPV isolates for this investigation. ICAR-Senior Research Fellowship for the first author is also gratefully acknowledged.

\section{Authors' contributions}

KSJ and AP planned and directed the experiment. RS and KRT conducted the experiment and prepared the manuscript draft. All authors have read and approved the final manuscript

\section{Funding}

Not applicable

\section{Availability of data and materials}

The datasets generated and/or analyzed during the current study are available in the GenBank database [https://www.ncbi.nlm.nih.gov/nucleotide]

\section{Ethics approval and consent to participate}

Not applicable

\section{Consent for publication}

Not applicable

\section{Competing interests}

The authors declare that they have no competing interests

\section{Author details}

'Department of Agricultural Entomology, University of Agricultural Sciences, GKVK campus, Bengaluru, Karnataka 560065, India. ${ }^{2}$ Department of Plant Biotechnology, University of Agricultural Sciences, GKVK, Bengaluru, Karnataka 560065, India.

Received: 21 May 2019 Accepted: 20 August 2019

Published online: 05 September 2019

\section{References}

Altschul SF, Gish W, Miller W, Myers EW, Lipman DJ (1990) Basic local alignment search tool. J Mol Bio 215:403-410

Arrizubi M, Williams T, Caballero P, Simon O (2013) Selection of a nucleopolyhedrosis isolate from Helicoverpa armigera as the basis for a biological insecticide. Pest Manag Sci 70:967-976

Bajya DR, Ranjith M, Raza SK (2015) Evaluation of Beauveria bassiana against chickpea pod borer, Helicoverpa armigera and its safety to natural enemies. Indian JAgr Sci 85(3):378-381

Barreto MR, Guimaraes CT, Teixeira FF, Paiva E, Valicente FH (2005) Effect of baculovirus Spodoptera isolates in Spodoptera frugiperda (J.E.Smith) (Lepidoptera: Noctuidae) larvae and their characterization by RAPD. Neotrop Entomol 34:67-75

Blissard GW, Rohrmann GF (1990) Baculovirus diversity and molecular biology. Annu Rev Entomol 35:127-155

Deng W, Maust BS, Nickle DC, Learn GH, Liu Y, Heath L, Kosakovskypond SL, Mullins JI (2010) DIVEIN: a web server to analyze phylogenies, sequence divergence, diversity, and informative sites. Bio Techniques 48:405-408

Figueiredo E, Munoz D, Escribano A, Mexia A, Vlak JM, Caballero P (1999) Biochemical identification and comparative insecticidal activity of nucleopolyhedrovirus isolates pathogenic for Heliothis armigera (Lepidoptera: Noctuidae) larvae. J Appl Ent 123:165-169

Figueiredo E, Muñoz D, Murillo R, Mexia A, Caballero P (2009) Diversity of Iberian nucleopolyhedrovirus wild-type isolates infecting Helicoverpa armigera (Lepidoptera: Noctuidae). Biol Control 50:4-49

Fitt GP (1989) The ecology of Heliothis species in relation to agro-ecosystems. Ann Rev Entomol 34:17-52
Gettig RR, McCarthy WJ (1982) Genotypic variation among wild isolates of Heliothis spp. nuclear polyhedrosis viruses from different geographical regions. Virol 117:245-252

Grzywacz D, Rabindra RJ, Brown M, Jones KA, Parnell M (2004) The Helicoverpa armigera nucleopolyhedrosis virus production manual, natural resources institute, http://www.fao.org/docs/eims/upload/agrotech/2011/hanpvmanual-pt1.pdf

Gupta RK, Raina JC, Arora RK, Bali K (2010) Selection and field effectiveness of nucleopolyhedrosis virus isolates against Helicoverpa armigera (Hubner). Int J Virol 6(3):164-178

Hefferon KL (2004) Baculovirus late expression factors. Review: J Mol Microbiol Biotechnol 7:89-101

Hodgson DJ, Vandergen AJ, Hartley SE, Hails RS, Cory JS (2002) Differential selection of baculovirus genotypes mediated by different species of host food plant. Ecol Lett 5:512-518

Jakubowska A, Oers MMV, Zeimnicka J, Lipa JJ, Vlak JM (2005) Molecular characterization of Agrotis segetum nucleopolyhedrovirus from Poland. J Invertebr Pathol 90:64-68

Jehle JA, Blissard GW, Bonning BC, Cory JS, Herniou EA, Rohrmann GF, Theilmann DA, Thiems SM, Vlak JM (2006) On the classification and nomenclature of baculoviruses: a proposal for revision. Arch Virol 151:1257-1266

Jones DT, Taylor WR, Thornton JM (1992) The rapid generation of mutation data matrices from protein sequences. Comput Appl Biosci 8:275-282

Kaur B, Gupta VK, Jindal V (2014) Molecular phylogenetic analysis of Indian strains Helicoverpa armigera nucleopolyhedrovirus (HearNPV). Indian J Biotechnol 13: 186-194

Kimura M (1980) A simple method for estimating evolutionary rate of base substitutions through comparative studies of nucleotide sequences. J Mol Evol 16:111-120

Lange M, Wang H, Zhihong H, Jehle JA (2004) Towards a molecular identification and classification system of lepidopteran specific baculoviruses. Virol 325:36-47

Mehrvar A, Rabindra RJ, Veenakumari K, Narabenchi GB (2008) Molecular and biological characteristics of some geographic isolates of nucleopolyhedrovirus of Helicoverpa armigera (Lepidoptera: Noctuidae). J Entomol Soc Iran 28:39-60

Moore SD, Bouwer G, Pittway TM (2004) Evaluation of Helicoverpa armigera nucleopolyhedrosis virus (HearNPV) for control of Helicoverpa armigera (Lepidoptera: Noctuidae) on citrus in South Africa. Biocontrol Sci Technol 14: 239-250

Ogembo JG, Chaeychomsri S, Kamiya K, Ishikawa H, Katou Y, Ikeda M, Kobayashi M (2007) Cloning and comparative characterization of nucleopolyhedrosis virus isolated from African bollworm, Helicoverpa armigera (Lepidoptera: Noctuidae) in different geographic region. J Insect Biotechnol Sericol 76:39-49

Patel CS, Jani JJ, Parekh VB, Darji VB, Vaishnav PR (2009) Genetic diversity and differentiation of Helicoverpa armigera nuclear polyhedrosis virus isolates from India. Phytoparasitica 37:407-413

Pugalenthi P, Dhanasekaran S, Elumali K, Krishnappa K (2013) Bio-efficacy of NPV tested against American bollworm, Helicoverpa armigera (Hub.) (Lepidoptera: Noctuidae) and protection of cotton boll damage. Int J Renew Environ Sci 1(3):22-26

Reed W, Pawar CS (1982) Heliothis: a global problem. Int. In: Workshop Heliothis Management, Patancheru, India, 1981.Patanchern, India: ICRISAT, pp 9-14

Rohrmann GF (1986) Polyhedrin sutructure. Review: J Gene Virus 67:1499-1513

Rowley DL, Popham HJR, Harrison RL (2011) Genetic variation and virulence of nucleopolyhedrosis virus isolated worldwide from the heliothine pests Helicoverpa armigera, Helicoverpa zea and Heliothis virescens. J Invertebr Patho |107:112-126

Sharma HC, Pampapathy G, Dhillon MK, Smith JTR (2005) Detached leaf assay to screen for host plant resistance to Helicoverpa armigera. J Econ Entomol 98(2):568-576

Swami D, Paul B, Kumar R (2012) Efficacy of new formulations of Bacillus thuringiensis var. kurstaki (HD-1) against Helicoverpa armigera (Hübner). J Biol Control 26(1):29-33

Takatsuka J, Okuno S, Nakai M, Kunimi Y (2003) Genetic and biological comparisons of ten geographical isolates of a nucleopolyhedrosis virus that infects Spodoptera litura (Lepidoptera: Noctuidae). Biol Control 26:32-39

Tamura K, Stecher G, Peterson D, Filipski A, Kumar S (2013) MEGA6: Molecuar evolutionary genetics analysis version 6.0. Mol Biol Evol 30:2725-2729

Wakil W, Ghazanfar MU, Sahi ST, Kwon YJ, Qayyum MA (2011) Effect of modified meridic diet on the development and growth of tomato fruit worm, Helicoverpa armigera (Lepidoptera: Noctuidae). Ent Res 41:88-94 
Wang $\mathrm{H}$, Wu D, Deng F, Peng H, Chen X, Lauzon H, Arif BM, Jehle JA, Hu Z (2004) Characterization and phylogenetic analysis of the chitinase gene from the Helicoverpa armigera single nucleocapsid nucleopolyhedrosis virus. Virus Res 100:179-189

Zhang CX, Ma XC, Guo ZJ (2005) Comparison of the complete genome sequence between $\mathrm{C} 1$ and G4 isolates of the Helicoverpa armigera single nucleocapsid nucleopolyhedrovirus. Virol 333:190-199

\section{Publisher's Note}

Springer Nature remains neutral with regard to jurisdictional claims in published maps and institutional affiliations.

Submit your manuscript to a SpringerOpen ${ }^{\circ}$ journal and benefit from:

- Convenient online submission

Rigorous peer review

- Open access: articles freely available online

High visibility within the field

- Retaining the copyright to your article

Submit your next manuscript at $\boldsymbol{\wedge}$ springeropen.com 